\title{
Meханізаиia, електриорікачіа
}

УДК 631.358

(C) 2021

\section{ОБҐРУНТУВАННЯ КОНСТРУКЦІЙНО- ТЕХНОЛОГІЧНОЇ СХЕМИ ПІДКОПУВАЛЬНО-СЕПАРУЮЧОГО РОБОЧОГО ОРГАНА КАРТОПЛЕЗБИРАЛЬНОЇ МАШИНИ}

\author{
B.В. Адамчук ${ }^{1}$, В.М. Корнюшин ${ }^{2}$ \\ ${ }^{\prime}$ доктор технічних наук, академік НАAН \\ Національний науковий центр «Інститут механізації \\ та електрифікації сільського господарства» \\ вул. Вокзальна, 11, смт. Глеваха Васильківського р-ну Київської обл., 08631, Україна \\ e-mail: ${ }^{1}$ vvadamchuk@gmail.com, ${ }^{2}$ korn_vik@ukr.net \\ ORCID: ${ }^{10000-0003-0358-7946, ~}{ }^{2} 0000-0002-1974-307 X$
}

Надійшла 28.05.2021

Мета. Підвищення якості роботи картоплезбиральної машини способом обґрунтування параметрів і удосконалення конструкції підкопувально-сепаруючого робочого органа. Методи. Аналітичні - під час аналізу конструкцій і технологічних процесів робочих органів картоплезбиральних машин. Математичні - за визначення параметрів робочих органів. Результати. Визначено, що підвищити показники якості роботи картоплезбиральних машин можна способом підвищення ефективності відокремлення ґрунтових домішок на сепаруючих робочих органах. Обґрунтовано конструкційно-технологічну схему та параметри підкопувально-сепаруючого робочого органа з пристроєм для рівномірного розподілу підкопаного картопляного вороху по ширині полотна прутково-елеваторного транспортера. Висновки. Лабораторно-польові дослідження картоплекопача КРК-2 і картоплекопача-навантажувача ККН-2 з новим підкопувально-сепаруючим робочим органом (параметри: діаметр барабана D=560 мм; висота прутка барабана H=250 мм; створ між барабанами A=350 мм; діаметр прутка $d_{n p}=18$ мм; колова швидкість обертання барабанів $V_{5}=2,8$ м/с; кількість прутків барабана к=20; довжина крила розподільника I=450 мм; висота крила $h=150$ мм; кут розхилу крила $\alpha=40-45^{\circ}$; зазор між розподільником і транспортером $\Delta=80$ мм; відстань між барабанами і розподільником $L=600$ мм) показали, що запропонований робочий орган підвищує показники якості роботи картоплезбиральних машин.

Ключові слова: збирання, бульби картоплі, домішки, конструкція, параметри.

DOI: https://doi.org/10.31073/agrovisnyk202106-06 
МЕХАНІЗАЦІЯ,

ЕЛЕКТРИФІКАЦІЯ

Обгрунтування конструкційно-технологічної

схеми підкопувально-сепаруючого робочого органа картоплезбиральної машини

Збирання картоплі - максимально трудомісткий технологічний процес її виробництва, на який припадає $45-60 \%$ загальних витрат праці [1]. Досвід експлуатації картоплезбиральних машин показує, що вони здатні задовільно виконувати агротехнічні вимоги лише під час роботи за сприятливих ґрунтово-кліматичних умов. За складних умов вони не завжди забезпечують якісне збирання картоплі, мають низьку надійність виконання технологічного процесу. В існуючих картоплезбиральних машинах основний сепаруючий робочий орган у вигляді прутково-елеваторного транспортера під час роботи за складних умов збирання незадовільно виконує свою функцію. Щоб отримати продукцію необхідної якості очищення доводиться працювати на знижених швидкостях і додатково обробляти бульби на картоплесортувальних пунктах, що призводить до збільшення витрат на збирання, оскільки потребує значних додаткових затрат праці, зокрема й ручної.

Поліпшити процес відокремлення ґрунтових домішок на сепаруючих робочих органах і показники якості роботи картоплезбиральних машин можна за рахунок уведення в технологічну схему інтенсифікуючих пристроїв, що додатково взаємодіють із підкопаним картопляним ворохом - у цьому полягає основна гіпотеза досліджень.

Аналіз останніх досліджень і публікацій. Дослідженнями шляхів удосконалення і процесів підкопування та сепарації вороху картоплезбиральними машинами займалися В.М. Булгаков, М.Е. Мацепуро, Г.Д. Петров, П.М. Настенко, М.Т. Ткачов, Б.Т. Скварски, М.М. Шумило, В.С. Бончик та ін. [2-9].

Було створено і досліджено велику кількість підкопувально-сепаруючих робочих органів. Переважно, це - комбінація підкопувальних робочих органів, які здійснюють процес підкопування, та додаткових пристроїв, що чинять інтенсивний вплив на підкопаний ворох. Серед додаткових пристроїв - різноманітні швирялки, бітери, шнеки, розпушувачі та сита, встановлені у зоні підкопування, що розпушують підкопаний шар і частково відокремлюють ґрунтові домішки. Однак аналіз показав, що запропоновані конструкції мають ті чи інші недоліки, тому актуальним $€$ розроблення вдосконаленого підкопувально-сепаруючого робочого органа картоплезбиральної машини.

Мета досліджень - підвищення якості роботи картоплезбиральної машини способом обґрунтування параметрів і удосконалення конструкції підкопувально-сепаруючого робочого органа.

Матеріали та методи досліджень. Аналіз конструкцій і технологічних схем сучасних картоплезбиральних машин та їх робочих органів. Математичними методами визначали основні параметри запропонованого підкопувально-сепаруючого робочого органа.

Результати досліджень. За незмінних параметрів сепаруючих робочих органів картоплезбиральної машини підвищення питомої продуктивності сепарації, тобто кількості ґрунтових елементів вороху (ГЕВ), що просіюється через одиницю площі поверхні сепаруючого транспортера за одиницю часу, залежить передусім від ступеня розпушення підкопаного шару вороху. Тому ефективність просіювання ГЕВ можна підвищити способом додаткового руйнування підкопаного шару вороху перед подачею його на сепаратор, рівномірним розподілом вороху по всій площі робочої поверхні сепаратоpa, та збільшенням часу перебування вороху на транспортері. Застосування одночасно кількох способів дасть змогу досягти підвищення показників очищення зібраних бульб.

Максимальне руйнування і розпушення ґрунтових елементів вороху динамічною дією без значних пошкоджень бульб можливе в зоні підкопування картопляного пласта бітерами, встановленими над приймальною частиною основного транспортера, які одночасно з подачею підкопаної маси на транспортер, руйнують шар вороху. Перспективними $є$ вертикальні пруткові барабани, встановлені між лемешем і транспортером [8]. Вони краще руйнують шар вороху і відсівають частину ГЕВ. Крім того, вони примусово подають підкопану масу з лемішів на сепаруючий транспортер i, таким чином, дають змогу уникнути надмірного скупчення вороху в приймальній частині машини.

Пруткові барабани характеризуються обмеженою зоною дії. Їх істотним недоліком 
МЕХАНІЗАЦІЯ,

ЕЛЕКТРИФІКАЦІЯ
Обгрунтування конструкційно-технологічної схеми підкопувально-сепаруючого робочого органа картоплезбиральної машини
$€$ нерівномірне завантаження за шириною транспортера, оскільки підкопаний шар вороху не розподіляється рівномірно на першому сепаруючому прутковому транспортері, а надходить у вигляді поздовжнього валка і, таким чином, основна маса вороху знаходиться в центральній частині транспортера. За подальшого руху ворох під динамічною дією струшувачів частково розрівнюється по ширині полотна транспортера, але цього недостатньо, щоб забезпечити якісну сепарацію ґрунту. Під час такого розподілу вороху на транспортері незадовільно виконується і процес руйнування ГЕВ балонами-подрібнювачами, оскільки для їх ефективної роботи потрібно, щоб грудки і бульби проходили між ними рівномірним тонким шаром.

Інтенсифікувати процес сепарації на транспортері можна шляхом рівномірного розподілу вороху по його ширині. Аналіз показує, що найбільш ефективними є пристрої, які безпосередньо взаємодіють із ворохом. Оскільки підкопаний пласт перед подачею на основний транспортер добре подрібнюється прутковими барабанами,

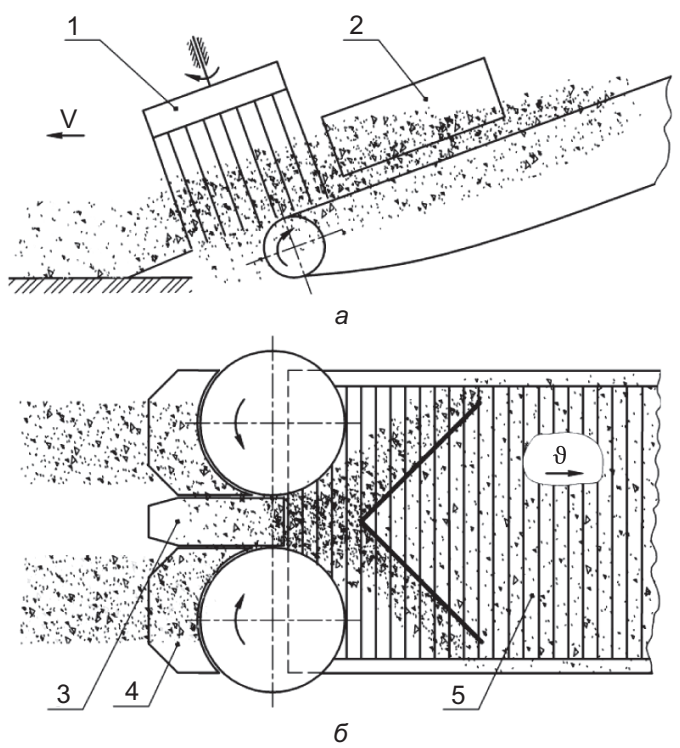

Рис. 1. Підкопувально-сепаруючий робочий орган картоплезбиральної машини: а - вигляд збоку; б - вигляд зверху: 1 - пруткові барабани; 2 - розподільник; 3, 4 - лемеші; 5 - прутково-елеваторний транспортер то в такому випадку для рівномірного розподілу вороху перспективним є пасивний робочий орган - розподільник V-подібного типу [10]. Під час використання органа такого типу ворох довше знаходиться на полотні транспортера за рахунок його пригальмовування, що підвищує повноту сепарації.

У результаті аналізу відомих конструктивно-технологічних рішень побудови засобів збирання картоплі було запропоновано конструкційно-технологічну схему підкопувально-сепаруючого робочого органа картоплезбиральної машини (рис. 1). Технологічний процес роботи картоплезбиральної машини із запропонованим робочим органом виконується так. Під час руху машини бічні лемеші (4) підкопують два суміжні рядки картоплі. Пруткові барабани (1) обертаються назустріч один одному, прутками захоплюють і розпушують підкопаний лемешами шар картопляної грядки та одночасно переміщують його на сепаруючий транспортер (5). Підкопаний ворох, рухаючись по транспортеру (5), потрапляє на розподільник (2), який складається з 2-х крил, розхилених на кут. Розподільник установлено за прутковими барабанами над сепаруючим транспортером. Водночас загальний потік вороху розподіляється на два потоки, що починають рухатися вздовж крил розподільника. Частина вороху проходитиме під розподільником, оскільки він установлений із зазором відносно поверхні транспортера. Рухаючись уздовж крил, ворох розподіляється по ширині транспортера, а завдяки наявності зазору - вирівнюється по висоті. Таким чином, після розподільника (2) формується рівномірно розподілений по ширині сепаруючого транспортера (5) потік розпушеного вороху, який подається до наступних робочих органів.

Подальший етап - розробка компонувальної схеми та конструкції запропонованого робочого органа для картоплезбиральної машини (рис. 2).

Як відомо, підкопувальний робочий орган повинен повністю підкопувати шар ґрунту з бульбами та ефективно передавати його на сепаруючий робочий орган [9]. Застосовуємо найпростіший робочий орган - плоский пасивний леміш. Для 
МЕХАНІЗАЦІЯ,

ЕЛЕКТРИФІКАЦІЯ
Обгрунтування конструкційно-технологічної

схеми підкопувально-сепаруючого робочого органа картоплезбиральної машини забезпечення самоочистки лемеша від рослинних решток він виконаний з трьох секцій. За заданими параметрами картопляної грядки, а саме - шириною міжряддя, профілем грядки, вимірами залягання гнізда бульб, а також шириною сепаруючого транспортера, графооналітичним методом визначимо раціональні геометричні параметри такого підкопувального органа.

Максимальна ширина гнізда бульб для різних сортів становить $b=23-32 \mathrm{~cm}$, максимальна глибина залягання нижньої бульби $-\mathrm{c}=21 \mathrm{~cm}$. Згідно з рекомендаціями [9] ширину підкопувального робочого органа $\mathrm{H}_{л}$ потрібно приймати в межах 450-500 мм для компенсації відхилень центру гнізда від середньої лінії рядка і неточності ведення агрегату. Тоді, за ширини міжрядь 700 мм, загальна ширина підкопування становить 1150-1200 мм. Приймаємо ширину бокових лемешів $\mathrm{H}_{\text {л }}=480$ мм, тоді ширина середнього лемеша з урахуванням зазора для сходу рослинних решток між лемешами становить $\mathrm{H}_{\text {лс }}=180 \mathrm{mм}$.

Установлюється максимально можливий кут нахилу лемеша $\beta$ з урахуванням того, що переміщення підкопаного шару забезпечується, якщо куті $\beta$ - не більше $24^{\circ}$. Довжина лемеша $L_{\text {л }}$ визначається за параметрами сепаруючого транспортера, а саме - висотою розміщення та діаметром передніх роликів пруткового транспортера, які вибираємо з умови проходу полотна транспортера під час огинання роликів без дотику до дна борозни. Крім того, слід забезпечити зазор між кронштейнами лемешів та дном борозни не менше 50 мм. Для самоочищення лез на кожному лемеші по краях виконано зрізи для сходу рослинних решток. Кут сходу становить 40-50. Середній леміш обладнано відкидними пальцями в місці переходу вороху з лемеша на транспортер для запобігання втрат і заклинювання каміння між прутками і заднім обрізом лемеша. Довжина лемешів становить $L_{\text {л }}=475$ мм. Крім того, у бокових лемешах вирізано отвори, які відповідають діаметрам барабанів. Щоб підкопаний пласт не розвалювався в сторони, а також для обмеження забору ущільненого шару ґрунту з міжрядь, по боках крайніх лемешів установлено обрізні пасивні диски.
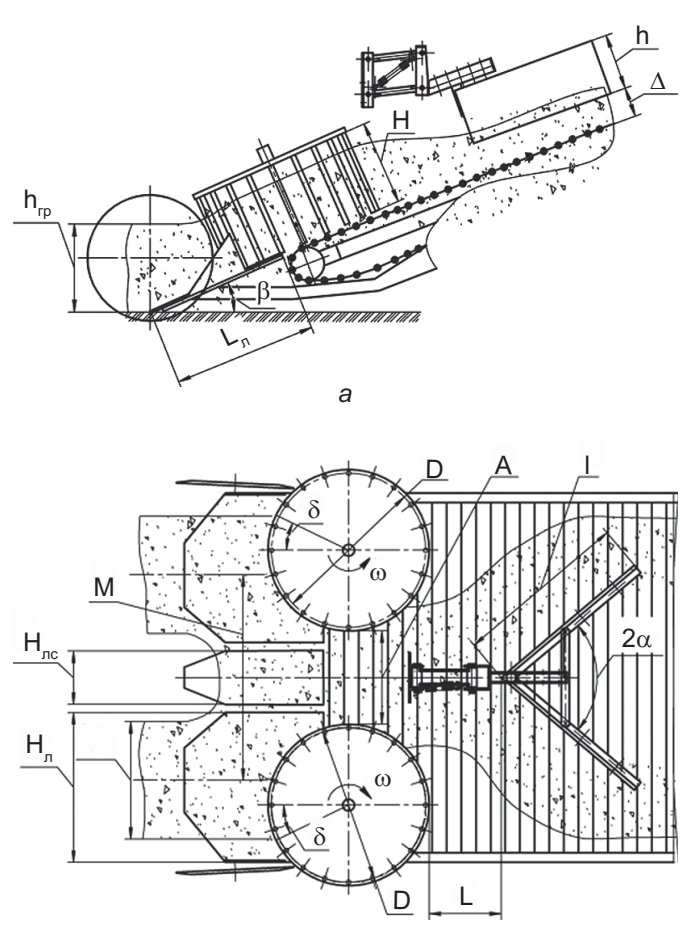

6

Рис. 2. Компонувальна схема підкопувально-сепаруючого робочого органа картоплезбиральної машини: а - вид спереду; б - вид зверху

Пруткові барабани встановлюються в зоні переходу підкопаного вороху з лемешів на сепаруючий транспортер, причому вісь обертання барабанів перпендикулярна до поверхні лемешів.

Координати установки барабанів визначаються технологічною вимогою - забезпечення подачі вороху з лемешів на транспортер. Вона виконуватиметься, якщо вісі обертання барабанів і передніх роликів транспортера перебуватимуть в одній площині. Відстань між осями барабанів визначається $з$ умови:

$$
D+A+\frac{D}{2} \sin \delta>M+I_{r p},
$$

де D - діаметр барабана, мм; A — створ між барабанами, мм; $\delta$ - кут захвату, $\delta<10^{\circ}$; M - ширина міжрядь посадки картоплі,

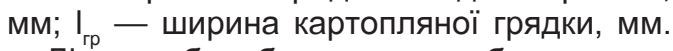

Діаметр барабана повинен бути максимально-можливим, оскільки з його збільшен- 
МЕХАНІЗАЦІЯ,

ЕЛЕКТРИФІКАЦІЯ

Обґрунтування конструкційно-технологічної

схеми підкопувально-сепаруючого робочого органа картоплезбиральної машини

ням підвищується ефективність захвату вороху. Максимальний діаметр пруткового барабана визначається за формулою [8]:

$$
\mathrm{D}_{\max }=\frac{3 \mathrm{M}-\mathrm{I}_{\mathrm{rp}}-2 \mathrm{a}-\mathrm{A}}{2},
$$

де а - ширина захисної смуги, мм.

Тоді діаметр барабана за забезпечення умови (2) становить:

$$
D>\frac{M+I_{г p}-A}{1+\frac{1}{2} \sin \delta} .
$$

Створ між барабанами має бути достатнім для проходження підкопаного вороху з двох рядків картоплі. Для цього слід виконати умову:

$$
2 \frac{2}{3} \mathrm{I}_{\mathrm{rp}} \mathrm{h}_{\mathrm{rp}}=\mathrm{AH}
$$

де $\mathrm{h}_{\text {гр }}$ - висота картопляної грядки, мм; H - висота прутка барабана, мм. Приймаємо $\mathrm{H}=(1,1 \ldots 1,2) \mathrm{h}_{\text {гр }}$.

Тоді:

$$
A=\left.(1,1 \ldots 1,2)\right|_{\text {гр }} .
$$

Використовуючи залежності (1), (2), (3) і (5), отримуємо такі конструкційні параметри пруткових барабанів: діаметр барабана - D=560 мм; висота прутка барабана - H=250 мм; створ між барабанами A $=350$ мм; діаметр прутка $-\mathrm{d}_{\text {пр }}=18$ мм.

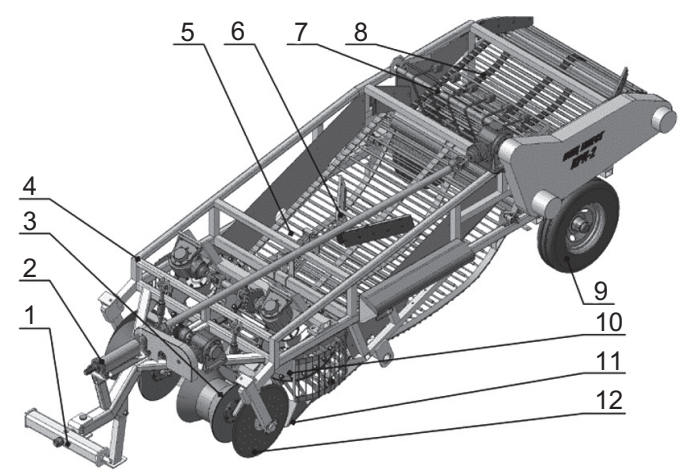

Рис. 3. Загальний вигляд картоплекопача з новим підкопувально-сепаруючим робочим органом: 1 - причіпний пристрій; 2 - приводний механізм; 3 - опорні котки; 4 - рама; 5 - основний транспортер; 6 розподільник; 7 - пристрій бадиллєвідокремлюючий; 8 - каскадний транспортер; 9 - опорні колеса; 10 - пруткові барабани; 11 - лемеші; 12 - обрізні диски
Швидкість обертання барабанів визначаємо з урахуванням вимог, щоб бульби картоплі не пошкоджувалися і не потрапляли всередину барабанів, - ці параметри обґрунтовано в праці [11]. Приймемо кінематичний параметр режиму роботи пруткових барабанів $\lambda=2,8$, тоді за середньої швидкості руху машини $\mathrm{V}_{\mathrm{M}}=1,0 \mathrm{~m} / \mathrm{c}$ колова швидкість обертання барабанів становитиме $V_{5}=2,8 \mathrm{~m} / \mathrm{c}$. Відповідно кутова швидкість барабанів буде $\omega=10$ рад/с (за $\mathrm{R}=0,28 \mathrm{~m}$ ), а частота обертання $\mathrm{n}=1,6 \mathrm{c}^{-1}$. Користуючись раніше проведеними теоретичними дослідженнями визнача$є м о$, що кількість прутків барабана - к $=20$ (крок установки прутків - 86 мм).

Пруткові барабани приводяться в обертовий рух від валу відбору потужності трактора через механічну передачу.

Параметри розподільника, а саме кут розхилу крила, зазор між розподільником і транспортером, відстань між барабанами і розподільником вибираємо з урахуванням проведених експериментальних досліджень [12].

Довжина крила I розподільника має бути мінімальною, достатньою для якісного розподілу вороху по поверхні сепаратора. Кут розхилу крил $2 \alpha$ встановлюємо максимально можливим. Крім того, слід передбачити регулювання цього кута для різних ґрунтово-кліматичних умов. Зазор між крилом розподільника та площиною транспортера $\Delta$ має бути оптимальним, тому також треба передбачити регулювання цього параметра у відповідних межах. Крім того, оскільки полотно транспортера постійно здійснює коливальні рухи з досить значною амплітудою, то розподільник необхідно встановлювати з можливістю забезпечення незмінного заданого розміру зазора. Відстань між барабанами та носком розподільника $L$ має бути мінімальною, але забезпечувати вільне проходження вороху.

Параметри розподільника з урахуванням ширини полотна транспортера визначаємо так: довжина крила розподільника I=450 мм; висота крила - h=150 мм; кут розхилу $-\alpha=40-45^{\circ}$; зазор $-\Delta=80$ мм; відстань між барабанами і розподільником $-\mathrm{L}=600 \mathrm{мм}$.

3 урахуванням одержаних параметрів підкопувально-сепаруючого робочого органа 
МЕХАНІЗАЦІЯ,

ЕЛЕКТРИФІКАЦІЯ

Обгрунтування конструкційно-технологічної

схеми підкопувально-сепаруючого робочого органа картоплезбиральної машини

було розроблено конструкторську документацію та виготовлено дослідні зразки картоплезбиральних машин - картоплекопач КРК-2 (виготовлювач - ДКТБ ІМЕСГ) і картоплекопач-навантажувач ККН-2 (виготовлювач - ВАТ «БОРЕКС»).

На рис. 3 показано загальний вигляд картоплекопача з новим підкопувально-сепаруючим робочим органом.

Проведені експериментальні лабораторно-польові дослідження зазначених зразків картоплезбиральних машин довели досить високу ефективність запропонованого робочого органа [13]. Картоплекопач із розробленим підкопувально-сепаруючим робочим органом, конструкція якого передбачає розподільник вороху, під час збирання картоплі забезпечує зменшення втрат бульб у 3,1 раза (втрати $0,8 \%$ із розподільником і 2,5\% - без нього), за цієї умови пошкодження бульб становило $4,8 \%$, що відповідає агротехнічним вимогам.

Картоплекопач-навантажувач із розробленим підкопувально-сепаруючим робочим органом конструкція якого передбачає розподільник вороху, забезпечує максимальну ефективність збирання бульб - до 99,4 \%, за умови, що ступінь очищення бульб у тарі становить $97,4 \%$ (без розподільника - 85,8\%) за допустимого пошкодження бульб 4,6\%.

\section{Висновки}

3 метою підвищення якості роботи картоплезбиральної машини запропоновано нову конструкційно-технологічну схему підкопувально-сепаруючого робочого органа. Визначено основні його параметри: діаметр барабана $-D=560$ мм; висота прутка барабана - H=250 мм; створ між барабанами - $A=350$ мм; діаметр прутка $-d_{\text {пр }}=18$ мм; колова швидкість обертання барабанів $-V_{5}=2,8$ м/c; кількість прутків барабана - к=20; довжина крила розподільника - I=450 мм; висота крила - $h=150$ мм; кут розхилу крила $\alpha=40-45^{\circ}$; зазор між розподільником і транспортером - $\Delta=80$ мм; відстань між барабанами і розподільником $-L=600$ мм.

Проведені експериментальні лабораторно-польові дослідження нового картоплекопача КРК-2 (виготовлювач - ДКТБ IMECГ) і картоплекопача-навантажувача ККН-2 (виготовлювач - ВАТ «БОРЕКС») показали, що запропонований робочий орган підвищує показники якості роботи картоплезбиральних машин.

\begin{abstract}
Adamchuk V. ${ }^{1}$, Korniushyn V. ${ }^{2}$
${ }_{1,2} \mathrm{NSC}$ «Institute of Mechanization and Electrification of Agriculture», 11, Vokzalna Str., Hlevakha, Vasylkiv district, Kyiv oblast, 08631, Ukraine, e-mail: ${ }^{1} v$ vadamchuk@gmail.com, 2korn_vik@ukr. net, ORCID: ${ }^{10000-0003-0358-7946, ~}{ }^{20} 0000-0002-$ 1974-307X
\end{abstract}

\section{Substantiation of the construction and techno- logical scheme of the underground separatory working body of the potato harvesting machine}

Goal. To improve the quality of the potato harvester by substantiating the parameters and improving the design of the digging and separating working body. Methods. Analytical - during the analysis of structures and technological processes of working bodies of potato harvesters. Mathematical — for determining the parameters of the working bodies. Results. It is determined that it is possible to increase the quality indicators of potato harvesters by increasing the efficiency of the process of separation of soil impurities on the separating working bodies. The construction-technological scheme and parameters of the digging-separating working body with the device for uniform distribution of the dug-up potato heap on the width of a cloth of the rod-elevator conveyor are substantiated. Conclusions. Laboratory field studies of potato digger KRK-2 and potato digger loader $\mathrm{KKN}-2$ with a new digging and separating working body (parameters: drum diameter $\mathrm{D}=560 \mathrm{~mm}$; height of drum bar $\mathrm{H}=250 \mathrm{~mm}$; alignment between drums $A=350 \mathrm{~mm}$; diameter rod $\mathrm{d}_{\mathrm{r}}=18 \mathrm{~mm}$; circular speed of rotation of the drums $\mathrm{V}_{\mathrm{D}}=2.8 \mathrm{~m} / \mathrm{s}$; number of drum rods $\mathrm{k}=20$, length of the distributor wing $\mathrm{I}=450 \mathrm{~mm}$, wing height $\mathrm{h}=150 \mathrm{~mm}$, angle of the wing $\alpha=40-45^{\circ}$, gap between the distributor and the conveyor $\Delta=80 \mathrm{~mm}$; distance between the drums and the distributor $L=600 \mathrm{~mm}$ ), showed that the proposed working body improves the quality of potato harvesters.

Key words: harvesting, potato tubers, impurities, design, parameters.

DOI: https://doi.org/10.31073/agrovisnyk202106-06 


\section{Бібліографія}

1. Верещагин Н.И., Пшеченков К.А., Герасимов В.C. Уборка картофеля в сложных условиях. Москва: Колос, 1983. 208 с.

2. Bulgakov V., Ivanovs S., Adamchuk V., Ihnatiev $Y$. Investigation of the influence of the parameters of the experimental spiral potato heap separatoron the quality of work. Agronomy Research. 2017.V. 15, № 1. P. 44-54.

3. Адамчук В.В., Булгаков В.М., Ружило З.В., Головач І.В., Іанатьєв Є.І. Експериментальне дослідження та обґрунтування параметрів сепаратора картопляного вороху. Вісник аграрної науки. 2020. № 7. С. 60-66.

4. Karwowski T. Teoria i konstrukcia maszyn rolniczych. T. 3. Warszawa: PWRiL, 1982. 429 p.

5. Farhadi R., Sakenian N., Azizi P. Design and construction of rotary potato grader. Bulgarian Journal of Agricultural Science. 2012. V. 18. P. 304-314.

6. Klindtworth M. Potato Technology. Jahrbuch Agritechnik (Frerichs L. Edit.) 2015. P. 1-12.

7. Aniket U., Dongre, Battase R., Dudhale S., Patil V. R., Chavan D. Development of potato harvesting model. International Research J. of Engineeringand Technology. 2017. V. 4. P. 1567-1570.

8. Завгородний А.Ф., Шумило М.М. Комби- нированный подкапывающе-сепарирующий орган картофелеуборочных комбайнов. Техника в сельском хозяйстве. 1986. № 10. С. 60-61.

9. Петров Г.Д. Картофелеуборочные машины. Москва: Машиностроение, 1984. 320 с.

10. Корнюшин В.М. Пат. № 63436А Україна, МПК A01D 17/00. Підкопувально-сепаруючий пристрій картоплезбиральної машини. заявник і патентовласник Національний науковий центр «Інститут механізації та електрифрікації сільського господарства» НААН. №2003043510; заявл. 18.04.2003; опубл. 15.01.2004. Бюл. № 1. 2004.

11. Корнюшин В.М. Обґрунтування режиму роботи пруткових барабанів підкопувально-сепаруючого пристрою картоплезбиральної машини. Вісник аграрної науки. 2010. № 5.С. 123-126.

12. Корнюшин В.М. Експериментальне дослідження пристрою для підвищення сепаруючої здатності картоплезбиральної машини. Механізація та електрифікація сільського господарства. Вип. 87. 2003. С.154-160.

13. Корнюшин В.М. Результати експериментальних досліджень картоплезбиральних машин з новим підкопувально-сепаруючим робочим органом. Інженерія природокористування. Харків, 2021, № 2(20). C. 68-74. doi: 10.37700/enm.2021. 2(20).68-74 